\title{
PENGARUH KEPUASAN KERJA DAN MOTIVASI KERJA TERHADAP PRODUKTIVITAS KERJA KARYAWAN PADA SINGARAJA HOTEL
}

\author{
A. Sururin ${ }^{1}$, K.K. Heryanda ${ }^{2}$, R. Atidira ${ }^{3}$ \\ 123Jurusan Manajemen, Universitas Pendidikan Ganesha, Singaraja. \\ e-mail: anaririn82@gmail.com¹, krisna.heryanda@undiksha.ac.id², rahutama.atidira@undiksha.ac.id ${ }^{3}$
}

\begin{abstract}
Abstrak
Penelitian ini dilakukan untuk menguji pengaruh kepuasan kerja dan motivasi kerja terhadap produktivitas kerja karyawan pada Singaraja Hotel. Penelitian ini merupakan penelitian kuantitatif. Pengumpulan data dilakukan dengan metode kuesioner dan wawancara. Kemudian, data dianalisis dengan menggunakan metode analisis regresi linier berganda. Hasil penelitian menunjukkan bahwa kepuasan kerja dan motivasi kerja secara simultan berpengaruh positif dan signifikan terhadap produktivitas kerja karyawan pada Singaraja Hotel, kepuasan kerja berpengaruh positif dan signifikan terhadap produktivitas kerja karyawan pada Singaraja, dan motivasi kerja berpengaruh positif dan signifikan terhadap produktivitas kerja karyawan pada Singaraja Hotel.
\end{abstract}

Kata kunci : kepuasan kerja, motivasi kerja, produktivitas kerja

\begin{abstract}
This study was conducted to examine the effect of job satisfaction and work motivation on employee productivity at Singaraja Hotel. This research is a quantitative research. Data collection was carried out by questionnaire and interview methods. Then, the data were analyzed using multiple linear regression analysis methods. The results showed that job satisfaction and work motivation simultaneously had a positive and significant effect on employee work productivity at Singaraja Hotel, job satisfaction had a positive and significant effect on employee work productivity at Singaraja, and work motivation had a positive effect and significant on employee work productivity at Singaraja Hotel.
\end{abstract}

Keywords : job satisfaction, work motivation, work productivity

\section{PENDAHULUAN}

Manajemen sumber daya manusia merupakan bagian dari manajemen keorganisasian yang memfokuskan diri pada unsur sumber daya manusia. Kegiatannya meliputi perencanaan, pengadaan, pengembangan, pemelihara-an, serta penggunaan sumber daya manusia untuk mencapai tujuan baik secara individu maupun organisasi. Salah satu tujuan dari adanya manajemen sumber daya manusia adalah untuk memperbaiki tingkat produktivitas, memperbaiki kualitas kehidupan kerja, dan meyakinkan organisasi bahwa telah memenuhi aspek-aspek legal.

Manajemen sumber daya manusia yang berkualitas tidak hanya harus memuaskan perusahaan ataupun para pemilik usaha saja dengan menghasilkan profit yang optimal, namun juga harus memberi kepuasan bagi seluruh pegawai yang bekerja pada perusahaan tersebut, baik dari level top, middle maupun pegawai pelaksana faktor kepuasan kerja pegawai sangat penting artinya bagi perusahaan karena dengan adanya kepuasan bagi pegawai, diharapkan nantinya akan semakin meningkatkan kinerja dan berimbas pada 
peningkatan produktivitas perusahaan secara menyeluruh, atau dalam ilmu manajemen jasa dikenal dengan istilah "happy employee, happy customer", yang berarti sebelum memuaskan pelanggan, harus terlebih dahulu memberi kepuasan bagi pekerja, sehingga pekerja akan dengan senang hati dan tulus ikhlas memberi pelayanan yang optimal bagi customernya kepuasan kerja pada dasarnya merupakan hal yang bersifat individual, setiap individual memiliki tingkat kepuasan kerja yang berbeda-beda sesuai dengan keinginan dan sistem nilai yang dianutnya (Handoko, 2008).

Kepuasan kerja secara umum menyangkut sikap seseorang mengenai pekerjaannya. Karena menyangkut sikap, pengertian kepuasan kerja mencakup berbagai hal seperti kondisi dan kecenderungan perilaku seseorang. Kepuasan itu tidak tampak serta nyata, tetapi dapat diwujudkan dalam suatu hasil pekerjaan. Salah satu masalah yang sangat penting dalam bidang psikologi industri adalah mendorong karyawan untuk bekerja dengan lebih produktif. Untuk itu, perlu diperhatikan agar karyawan sebagai penunjang terciptanya produktivitas kerja dalam bekerja senantiasa disertai dengan perasaan senang dan tidak terpaksa sehingga akan tercipta kepuasan kerja para karyawan. Kepuasan kerja akan berbeda pada masing-masing individu. Sangat sulit untuk mengetahui ciri-ciri kepuasan dari masing-masing individu. Namun demikian, cerminan dari kepuasan kerja itu dapat diketahui. Kepuasan kerja berhubungan erat dengan faktor sikap dari karyawan terhadap pekerjaannya sendiri, situasi kerja, kerjasama antara pimpinan dengan sesama karyawan menurut As'ad (2009: 104). Sejalan dengan itu, Martoyo (2011:142) kepuasan kerja (job satifaction) adalah keadaan emosional karyawan di mana terjadi ataupun tidak terjadi titik temu antara nilai balas jasa kerja karyawan dari perusahaan atau organisasi dengan tingkat nilai balas jasa yang memang diinginkan oleh karyawan yang bersangkutan. Balas jasa kerja karyawan ini, baik yang berupa finansial maupun yang nonfinansial.

Selain kepuasan kerja karyawan, motivasi para karyawan juga diperlukan untuk meningkatkan produktivitas. Motivasi perlu dilakukan oleh pimpinan kepada para pegawainya sehingga produktivitas dapat meningkat. Bila seseorang termotivasi, ia akan berusaha berbuat sekuat tenaga untuk mewujudkan apa yang diinginkannya. Namun belum tentu upaya yang keras itu akan menghasilkan produktivitas yang diharapkan, apabila tidak disalurkan dalam arah yang dikehendaki organisasi. Oleh karena itu, upaya harus diarahkan dan lebih konsisten dengan tujuan ke dalam sasaran organisasi. Selama peneliti melakukan penelitian, peneliti mengamati bahwa tidak semua pegawai melakukan briefieng (apel pagi) bahkan hanya unit tertentu yang terkadang mengadakan rapat. Hal ini menjadi sangat penting karena karyawan sangatlah perlu motivasi setiap harinya. Seperti pada penelitian yang dilakukan oleh Samsuni yang menyebutkan bahwa produktivitas yang tinggi dapat dicapai jika didukung para karyawan yang mempunyai motivasi dalam melaksanakan tugas dan kewajibannya. Kepuasan kerja akan menjadi berbeda pada setiap individunya. Menjadi lebih sulit untuk mengetahui ciri-ciri dari kepuasan pada setiap individu. Namun demikian, dari cerminan kepuasan kerja itu dapat diketahui bahwa semuanya tergantung pada setiap individunya.

Produktivitas kerja merupakan tingkat keunggulan yang diharapkan dan pengendalian atas tingkat keunggulan untuk memenuhi keinginan konsumen. Produktivitas dimulai dari kebutuhan pelanggan dan berakhir pada persepsi pelanggan. Hal ini dapat diimplementasikan interaksi antara karyawan dan pelanggan yang mencakup (a) ketepatan waktu, berkaitan dengan kecepatan memberikan tanggapan terhadap keperluan-keperluan pelanggan; (b) penampilan karyawan, berkaitan dengan kebersihan dan kecocokan dalam berpakaian; (c) kesopanan dan tanggapan terhadap keluhan, berkaitan dengan bantuan yang diberikan dalam menyelesaikan masalah-masalah yang diajukan pelanggan Gaspersz (2009:130).

Saat ini persaingan hotel sangat tinggi agar hotel dapat bertahan dan berkembang pihak hotel harus proaktif dan memberikan jasa yang memuaskan kepada pelanggannya. Caranya adalah memahami persepsi pelanggan mengenai jasa di hotel serta menerapkannya sesuai dengan apa yang diinginkan pelanggan sehingga hotel akan mampu 
bertahan dan unggul dalam persaingan di era globalisasi saat ini. Para karyawan dituntut untuk dapat melaksanakan tugas yang dibebankan kepadanya lebih profesional, yang berarti karyawan yang mempunyai pandangan untuk selalu perpikir, kerja keras, bekerja sepenuh waktu, disiplin, jujur, loyalitas tinggi dan penuh dedikasi demi untuk keberhasilan pekerjaanya Hamid (2010: 40). Untuk itu, diperlukan adanya pembinaan dam ditumbuhkan kesadaran juga kemampuan kerja yang tinggi. Apabila pegawai dengan penuh kesadaran bekerja dengan optimal, maka tujuan organisasi akan lebih mudah tercapai.

Kepuasan kerja yang baik akan membuat karyawan semakin loyal kepada perusahaan atau organisasi. Semakin termotivasi dalam bekerja, bekerja dengan rasa tenang, dan yang lebih penting lagi kepuasan kerja yang tinggi akan memperbesar kemungkinan tercapainya produktivitas dan motivasi yang tinggi pula. Karyawan yang tidak merasa puas terhadap pekerjaanya. Bila seseorang termotivasi, ia akan berusaha berbuat sekuat tenaga untuk mewujudkan apa yang diinginkannya. Namun belum tentu upaya yang keras itu akan menghasilkan produktivitas yang diharapkan, apabila tidak disalurkan dalam arah yang dikehendaki organisasi. Oleh karena itu, upaya harus diarahkan dan lebih konsisten dengan tujuan ke dalam sasaran organisasi.

Berdasarkan fakta yang terjadi pada Hotel Singaraja dari hasil wawancara kepada HRD Hotel Singaraja pada pra survey diperoleh informasi bahwa manajer tingkat menengah sekelas supervisor dilihat kurang memiliki kedekatan kepada karyawan yang dipimpinnya dan juga kurang intens dalam memberikan motivasi kepada karyawan bawahannya (kepuasan terhadap supervisi atasan). Selain itu, kedekatan antar karyawan juga rendah sehingga lingkungan kerja yang terbentuk kurang kondusif (kepuasan dengan rekan kerja). Karena tidak adanya jaminan kesejahteraan yang diberikan oleh pihak hotel membuat para karyawan cenderung lebih cepat untuk mencari pekerajaan baru (jaminan kesejahteraan). Tidak adanya peningkatan atau promosi jabatan bagi karyawan yang sudah bekerja lebih lama (promosi), pada hari-hari tertentu para karyawan terkadang kerjanya tidak maksimal disaat ada tambahan jam kerja (semangat kerja), apabila ada lembur kerja bagi karyawan tidak diberikan bonus gaji tambahan (bonus). Menurut keterangan dari HRD Hotel Singaraja diketahui bahwa selama ini penyebab menurunnya produktivitas kerja karyawan Hotel Singaraja diindikasikan dengan beberapa faktor.

Bersumber pada fakta masalah yang dituangkan diatas, perlu informasi secara empirik mengenai kepuasan kerja dan motivasi kerja karyawan terhadap produktivitas kerja secara akurat untuk itu sebagai bahan pertimbangan dalam mengambil keputusan untuk memperbaiki, mencegah, memecahkan masalah terhadap kepuasan kerja, motivasi kerja dan produktivtias kinerja yang nantinya akan dihadapi oleh karyawan.

Sejalan dengan penelitian Marsono (2001) dimana variabel kepuasan dan motivasi kerja mempunyai pengaruh yang positif dan signifikan terhadap produktivitas kerja pegawai. Hal ini juga didukung oleh hasil penelitian empirik Wahyuddin (2016) yang menyatakan bahwa Kepuasan kerja dan motivasi berpengaruh secara simultan terhadap produktivitas kerja karyawan. Berdasarkan pada uraian latar belakang masalah diatas, maka penelitian memandang perlu untuk dilakukan penelitian yang dituangkan dalam judul "Pengaruh Kepuasan Kerja Dan Motivasi Kerja Terhadap Produktivis Kerja Karyawan Pada Singaraja Hotel".

Berdasarkan urain latar belakang di atas, terdapat identifikasi masalah sabagai berikut, (1) kurangnya pelatihan kerja karyawan dalam hal pelayanan tamu, (2) hubungan antar sesama rekan kerja kurang kondusif, (3) kurangnya adanya pengawasan dari atasan sehingga mengakibatkan karyawan bekerja kurang maksimal, (4) tidak adanya jaminan kesejahteraan bagi setiap karyawan hotel, dan (5) rendahnya jumlah kompensasi yang diberikan oleh hotel kepada karyawan.

Berdasarkan uraian latar belakang penelitian di atas, maka dalam menyusun penelitian ini penulis terlebih dahulu merumuskan masalah sebagai dasar kajian penelitian yang akan dilakukan yaitu sebagai berikut. Bagaimana pengaruh kepuasan kerja terhadap produktivitas kerja pada Singaraja Hotel, bagaimana pengaruh motivasi kerja terhadap produktivitas kerja 
pada Singaraja Hotel, serta bagaimana pengaruh kepuasan kerja dan motivasi kerja terhadap produktivitas kerja pada Singaraja Hotel.

Tujuan dari peneliian ini adalah unuk menguji hal-hal sebagai berikut, (1) pengaruh kepuasan kerja terhadap produktivitas kerja pada Singaraja Hotel, (2) pengaruh motivasi kerja terhadap produktivitas kerja pada Singaraja Hotel, dan (3) pengaruh kepuasan kerja, motivasi kerja terhadap produktivitas kerja pada Singaraja Hotel. Hasil dari penelitian ini diharapkan akan mempunyai manfaat secara teoritis dan praktis. Manfaat teoritis, hasil dari penelitian ini diharapkan dapat memberikan bahan yang bermanfaat sebagai pengembangan ilmu ekonomi pada bidang manajemen sumber daya manusia. Manfaat praktis, penelitian ini diharapkan dapat digunakan sebagai masukan dalam membantu memperbaiki dan meningkatkan produktivitas kerja sehingga dapat meningkatkan pelayanan kerja para karyawan pada Singaraja Hotel.

\section{KAJIAN PUSTAKA DAN PERUMUSAN HIPOTESIS Hubungan Kepuasan Kerja Terhadap Produktivitas Kerja}

Kepuasan kerja dalam pekerjaan adalah kepuasan kerja yang dinikmati dalam pekerjaan dengan memperoleh tujuan hasil kerja, penempatan, perlakuan dan suasana lingkungan kerja yang baik. Karyawan yang lebih suka menikmati kepuasan kerja dalam pekerjaan ini akan lebih mengutamakan pekerjaannya daripada balas jasa atau pelaksanaan tugas-tugasnya. Kepuasan kerja akan mendorong karyawan untuk berproduktivitas yang lebih baik dan tinggi. Produktivitas yang lebih baik akan menimbulkan imbalan ekonomi dan psikologis yang lebih tinggi. Apabila imbalan tersebut dipandang pantas dan adil maka timbul kepuasan yang lebih besar karena karyawan merasa bahwa mereka menerima imbalan sesuai dengan hasil kerja mereka. Melayu (2012: 202) menyatakan bahwa kepuasan kerja adalah sikap emosional yang menyenangkan dan mencintai pekerjaannya, sedangkan Handoko (2008: 193) menyatakan kepuasan kerja (job sastification) adalah keadaan emosional yang menyenangkan atau tidak menyenangkan dengan mana para karyawan memandang pekerjaan mereka. Sementara Usman (2010: 281) juga menyatakan bahwa kepuasan kerja adalah sikap seseorang terhadap pekerjaannya yang mencerminkan pengalaman yang menyenangkan dan tidak menyenangkan dalam pekerjaannya serta harapan-harapannya terhadap masa depan. Menurut Robbins (2011: 151) bahwa seorang pekerja yang bahagia adalah seorang pekerja yang produktif. Karyawan yang lebih puas dengan pekerjaannya cenderung menjadi lebih efektif daripada karyawan yang kurang puas. Karyawan yang bahagia atau puas dengan pekerjaannya akan memiliki produktivitas yang tinggi. Berdasarkan pemaparan tersebut maka dapat dirumuskan hipotesis sebagai berikut:

$\mathrm{H}_{1}$ : $\quad$ Ada pengaruh kepuasan kerja terhadap produktivitas kerja

\section{Hubungan Motivasi Kerja Terhadap Produktivitas Kerja}

Motivasi merupakan faktor pendorong dalam melakukan suatu aktivitas dan memiliki hubungan yang sangat besar terhadap produktivitas karyawan. Motivasi merupakan sebuah keahlian dalam mengarahkan karyawan pada tujuan perusahaan agar mau bekerja dan berusaha sehingga keinginan para karyawan dan tujuan perusahaan dapat tercapai. Motivasi seseorang melakukan suatu pekerjaan karena adanya suatu kebutuhan hidup yang harus dipenuhi. Kemudian Robbins dan Mary dalam Suwanto (2011: 171) juga merumuskan bahwa motivasi kerja sebagai kesediaan untuk melaksanakan upaya tinggi untuk mencapai tujuan-tujuan keorganisasian yang dikondisikan oleh kemampuan upaya untuk memenuhi kebutuhan individual tertentu. Kebutuhan ini dapat berupa kebutuhan ekonomis yaitu untuk memperoleh uang, sedangkan akan membuat motivasi kerja karyawan rendah dan perusahaan sulit mencapai target yang diinginkan. Kebutuhan nonekonomis dapat diartikan sebagai kebutuhan untuk memperoleh penghargaan dan keinginan lebih maju. Dengan segala kebutuhan tersebut, seseorang dituntut untuk lebih giat dan aktif dalam bekerja, untuk mencapai hal ini diperlukan adanya motivasi dalam melakukan pekerjaan, karena dapat mendorong seseorang bekerja dan selalu berkeinginan untuk melanjutkan usahanya. Oleh karena itu jika pegawai yang mempunyai motivasi kerja yang tinggi biasanya mempunyai 
produktivitas yang tinggi pula. Menurut Sirait (2006:249-252) salah satu faktor yang mempengaruhi produktivitas kerja karyawan adalah motivasi, dimana motivasi merupakan proses untuk mempengaruhi seseorang agar mau melakukan sesuatu. Produktivitas atau prestasi seseorang tergantung pada motivasi orang tersebut terhadap pekerjaan yang dilakukan. Semakin tinggi motivasi seseorang untuk melakukan pekerjaan, semakin tingggi pula tingkat produktivitasnya. Berdasarkan pemaparan tersebut maka dapat dirumuskan hipotesis sebagai berikut:

$\mathrm{H}_{2}$ : $\quad$ Ada pengaruh motivasi kerja terhadap produktivitas kerja.

Hubungan Kepuasan Kerja Dan Motivasi Kerja Terhadap Produktivitas Kerja

Berdasarkan teori Robbins (2011: 151) bahwa seorang pekerja yang bahagia adalah seorang pekerja yang produktif. Karyawan yang lebih puas dengan pekerjaannya cenderung menjadi lebih efektif daripada karyawan yang kurang puas. Karyawan yang bahagia atau puas dengan pekerjaannya akan memiliki produktivitas yang tinggi. Sedangkan menurut Sirait (2006:249-252) salah satu faktor yang mempengaruhi produktivitas kerja karyawan adalah motivasi, dimana motivasi merupakan proses untuk mempengaruhi seseorang agar mau melakukan sesuatu. Produktivitas atau prestasi seseorang tergantung pada motivasi orang tersebut terhadap pekerjaan yang dilakukan. Semakin tinggi motivasi seseorang untuk melakukan pekerjaan, semakin tinggi pula tingkat produktivitasnya. Dari teori yang sudah dijelaskan produktitivitas kerja karyawan dipengaruhi oleh kepuasan kerja dan motivasi kerja dari karyawan itu sendiri apabila karyawan yang merasa bahagia atau puas dengan pekerjaannya akan memiliki produktivitas yang tinggi, begitu juga semakin tinggi motivasi seseorang untuk melakukan pekerjaan, maka semakin tingggi pula tingkat produktivitasnya. Berdasarkan pemaparan tersebut maka dapat dirumuskan hipotesis sebagai berikut:

$\mathrm{H}_{3}$ : Ada pengaruh kepuasan kerja dan motivasi kerja terhadap produktivitas kerja.

\section{METODE}

Penelitian ini dilakukan untuk mengetahui pengaruh kepuasan kerja dan motivasi kerja terhadap produktivitas pada Singaraja Hotel. Menurut Sugiyono (2011), variabel bebas merupakan variabel yang mempengaruhi atau yang menjadi sebab perubahannya atau timbulnya variabel terikat. Dalam penelitian ini terdiri dari dua variabel bebas, yaitu kepuasan kerja $\left(\mathrm{X}_{1}\right)$, motivasi kerja $\left(\mathrm{X}_{2}\right)$, serta produktivitas kerja sebagai variabel terikat $(\mathrm{Y})$.

Berdasarkan karakteristik masalah yang diteliti maka penelitian ini menggunakan desain penelitian kuantitatif kausal. Desain penelitian kausal yaitu penelitian yang digunakan untuk menganalisis hubungan antara variabel satu dengan variabel lainnya. Dalam penelitian ini yang menjadi subyek penelitian adalah Singaraja Hotel, sedangkan objek dalam penelitian ini adalah kepuasan kerja, motivasi kerja, dan produktivitas kerja. Populasi yang digunakan dalam penelitian ini adalah 35 orang. Teknik pengambilan sampel dalam penelitian ini menggunakan teknik total sampling yaitu menggunakan seluruh karyawan pada Singaraja Hotel dijadikan objek pengamatan, maka penelitian ini juga termasuk penelitian populasi. Langkah-langkah penelitian kuantitatif kausal terdiri dari beberapa tahapan meliputi (1) merumuskan masalah, (2) mengkaji teori, (3) merumuskan hipotesis, (4) mengumpulkan data, (5) mengolah data, dan (6) menarik suatu kesimpulan.

Jenis data dalam penelitian ini adalah data kuantitatif. Data kuantitatif diperoleh melalui metode pengumpulan data dengan kuesioner, wawancara, dan pencatatan dokumen. Analisis data dalam penelitian ini menggunakan analisis regresi linier berganda. Sebelum data diinput ke program Statistical Product and Service Solution (SPSS) terlebih dahulu diuji pada uji asumsi klasik. Uji asumsi klasik dilakukan untuk mengetahui persamaan regresi. Penggunaan analisis regresi dalam statistik harus bebas dari asumsi-asumsi klasik seperti normalitas data, multikolinearitas, dan heteros-kedastisitas.

\section{HASIL DAN PEMBAHASAN Hasil}


Uji Normalitas bertujuan untuk menguji apakah residual data yang digunakan dalam model telah terdistribusi secara normal. Model yang baik adalah yang memiliki residual data yang terdistribusi normal. Metode yang lebih handal adalah dengan melibat normal probability plot yang membandingkan distribusi kumulatif dari distribusi normal (Ghozali, 2011). Uji normalitas dengan menggunakan metode normal probability plot menunjukkan, data berada disekitar garis diagonal, maka moel regresi memenuhi asumsi normalitas hal ini berarti bahwa model regresi tersebut berdistribusi normal.

Uji multikolinearitas bertujuan untuk menguji apakah dalam model regresi ditemukan adanya korelasi antar variabel bebas. Dalam model regresi yang baik seharusnya tidak terjadi korelasi di antara variabel bebas. Salah satu cara untuk mengetahui adanya gejala multikolinieritas adalah dengan melakukan perbandingan antara koefisien determinasi simultan variabel bebas terhadap variabel terikat pada fungsi regresi variabel tersebut dengan koefisien determinasi antara variabel bebaspada fungsi regresi auxilary. Apabila tolerance value lebih tinggi dari 0,10 atau variance inflation factor (VIF) lebih kecil daripada 10 maka disimpulkan tidak terjadi multikolinearitas.

Hasil uji multikorelasi menunjukan output nilai tolerance dari variabel kepuasan kerja lebih besar dari 0,1 atau $(0,122>0,1)$ dan nilai VIF lebih kecil dari 10 atau $(8,180<10)$ serta untuk variabel motivasi kerja nilai torelarance lebih besar dari $0,1(0,122>01)$ dan nilai VIF lebih kecil dari $10(8,180<10)$. Jadi dari pemaparan hasil output SPSS uji multikolinieritas dapat disimpulkan bahwa tidak ada gejala multikolinieritas dalam model regresi penelitian ini.

Dalam persamaan regresi berganda perlu juga diuji mengenai sama atau tidaknya varians dari residual observasi yang satu dengan observasi yang lainnya. Jika residualnya mempunyai varians yang sama, disebut terjadi gejala homoskedastisitas, dan jika variansnya berbeda disebut terjadi gejala heteroskedastisitas. Persamaan regresi yang baik adalah jika tidak terjadi heteroskedastisitas. Analisis uji asumsi Heteroskedastisitas dilakukan melalui grafik scatterplot (Ghozali, 2011).

Hasil uji heteroskedastisitas dengan scatter plot dapat diketahui bahwa titik-titik residual menyebar dengan pola yang tidak teratur di atas dan di bawah angka 0 (nol) pada sumbu Y. Dengan demikian dapat diambil kesimpulan bahwa pada model regresi tidak terdapat masalah heteroskedastisitas dan residu mempunyai ragam yang homogen, sehingga uji heteroskedastisitas dapat terpenuhi.

Hasil uji determinasi menunjukkan nilai $R$ Square sebesar 0,937 atau 93,7\%. Hal ini menunjukkan bahwa sumbangan pengaruh kepuasan kerja dan motivasi kerja terhadap produktivitas kerja karyawan Singaraja Hotel sebesar 93,7\%. Dalam arti lain variabel produktivitas kerja karyawan Singaraja Hotel dapat dijelaskan atau dipengaruhi oleh variabel kepuasan kerja dan motivasi kerja sebesar 93,7\%, sedangkan sisanya yaitu sebesar 6,3\% dijelaskan atau dipengaruhi oleh variabel lain yang tidak dimasukkan dalam model regresi pada penelitian ini.

Berdasarkan hasil analisis data pada variabel kepuasan kerja dan motivasi kerja terhadap produktivitas kerja pada Singaraja Hotel dengan menggunakan metode analisis regresi linier berganda yang dibantu oleh program Statistical Package for Social Science (SPSS) 23.0 for Windows, maka dapat diperoleh hasil analisis dengan persamaan sebagai berikut.

$Y=\alpha+\beta_{1} X_{1}+\beta_{2} X_{2}+\varepsilon$

$Y=2,643+0,633 X_{1}+0,463 X_{2}+1,208$

Berdasarkan persamaan regresi yang diperoleh dari hasil analisis data dengan metode analisis regresi berganda, maka interpretasi dari persamaan regresi tersebut dapat dijelaskan sebagai berikut.

a. Konstanta (a) sebesar 2,643 memiliki arti apabila variabel kepuasan kerja dan motivasi kerja nilainya 0 (nol), maka variabel produktivitas kerja nilainya sebesar 2,643. Jadi, apabila tidak ada kepuasan kerja dan motivasi kerja, maka nilai produktivitas kerja sebesar 2,643 satuan. 
b. Koefisien regresi variabel kepuasan kerja $\left(X_{1}\right)$ sebesar 0,633 memiliki arti apabila variabel kepuasan kerja meningkat sebesar 1 satuan, maka variabel produktivitas kerja mengalami kenaikan yaitu sebesar 0,633 satuan. Koefisien bernilai positif berarti terdapat hubungan yang searah variabel kepuasan kerja terhadap produktivitas kerja. Apabila kepuasan kerja dalam bekerja tinggi, maka akan meningkatkan produktivitas kerja.

c. Koefisien regresi variabel motivasi kerja $\left(\mathrm{X}_{2}\right)$ sebesar 0,463 memiliki arti apabila variabel motivasi kerja meningkat sebesar 1 satuan, maka variabel produktivitas kerja mengalami kenaikan sebesar 0,463 satuan. Koefisien bernilai positif berarti terdapat hubungan yang searah variabel motivasi kerja terhadap produktivitas kerja. Apabila motivasi kerja tinggi, maka akan meningkatkan produktivitas kerja. Sebaliknya, apabila motivasi kerja rendah, maka akan menurunkan produktivitas kerja. 


\section{Pembahasan}

Hasil penelitian hipostesis pertama menunjukkan bahwa kepuasan kerja karyawan Singaraja Hotel belum optimal. Hal ini ditunjukkan dari para karyawan merasa kurang puas karena pimpinan yang kurang memberikan perhatian terhadap karyawan dan pimpinan juga tidak memberikan kesempatan kepada karyawan dalam memberikan ide-ide, selain itu beberapa karyawan kurang beradaptasi dengan karyawan yang lainnya dan kurangnya kerjasama tim yang solid, yang mengakibatkan prestasi dan moral kerja menurun, kurangnya disiplin karyawan dalam bekerja, serta keinginan karyawan untuk mencari pekerjaan di tempat lain meningkat. Berdasarkan hasil penelitian yang dilakukan menunjukkan bahwa nilai thitung untuk variabel kepuasan kerja sebesar 4.561 lebih besar dari nilai $t_{\text {tabel }}$ sebesar 1,693 dengan tingkat signifikansi $0,000<0,05$, hingga $\mathrm{H}_{0}$ ditolak dan $\mathrm{H}_{\mathrm{a}}$ diterima. Kepuasan kerja berpengaruh signifikan terhadap produktivitas kerja pada Singaraja Hotel. Hasil penelitian ini sesuai dengan penelitian yang dilakukan Manafe (2018) menunjukan hasil bahwa kepuasan kerja berpengaruh pada produktivitas kerja karyawan. Selanjutnya penelitian oleh Wahyuddin (2016) yang menyatakan bahwa kepuasan kerja berpengaruh positif dan signifikan terhadap produktivitas kerja pegawai. Kemudian Malonda (2013) yang menyatakan hasil penelitiannya bahwa kepuasan kerja mempunyai pengaruh signifikan terhadap produktivitas kerja karyawan. Hal ini ditunjukkan dari peningkatan kepuasan kerja karyawan dengan adanya pemberian bonus berupa tambahan kepada karyawan yang dapat menyelesaikan pekerjaan melebihi target yang telah ditentukan perusahaan.

Hasil penelitian hipostesis kedua menunjukkan bahwa motivasi kerja karyawan Singaraja Hotel belum optimal. Hal ini ditunjukkan dari kinerja karyawan yang dinilai cukup baik karena kurangnya pengarahan dan pembinaan yang diberikan oleh pimpinan. Kurang optimal motivasi karyawan juga ditunjukkan dari masih kurangnya penghargaan seperti bonus yang diberikan perusahaan kepada karyawan yang memiliki prestasi kerja yang baik. Para karyawan juga merasa tidak dapat berpartisipasi dalam memberikan ide dan tidak mendapatkan kesempatan untuk maju dalam jenjang karir. Secara keseluruhan motivasi kerja karyawan dalam kategori cukup baik yang artinya motivasi kerja karyawan harus ditingkatkan karena kondisi ini dapat mempengaruhi produktivitas kerja karyawan. Berdasarkan hasil penelitian yang dilakukan menunjukkan bahwa nilai thitung untuk variabel motivasi kerja sebesar 3.180 lebih besar dari nilai ttabel sebesar 21,693 dengan tingkat signifikansi.0,003 $<0,05$, hingga $\mathrm{H}_{0}$ ditolak dan $\mathrm{H}_{\mathrm{a}}$ diterima. Motivasi kerja berpengaruh signifikan terhadap produktivitas kerja pada Singaraja Hotel. Hasil penelitian ini sesuai dengan penelitian oleh Manafe (2018) yang menunjukkan hasil bahwa motivasi kerja berpengaruh pada produktivitas kerja karyawan. Penelitian Wahyuddin (2016) juga menunjukkan motivasi kerja berpengaruh positif dan signifikan terhadap produktivitas kerja pegawai. Selanjutnya hasil penelitian Pramadewi (2014) menunjukkan bahwa motivasi kerja berpengaruh signifikan terhadap produktivitas kerja karyawan. Kemudian penelitian menurut Sirait (2006: 249-252) salah satu faktor yang mempengaruhi produktivitas kerja karyawan adalah motivasi, dimana motivasi merupakan proses untuk mempengaruhi seseorang agar mau melakukan sesuatu. Hal ini ditunjukkan dari minat yang tinggi terhadap pekerjaannya. Para karyawan lebih sesuai dengan apa yang menjadi keinginannya, sedang bekerja dan merasa bahwa kebijakan dari pimpinan sesuai dengan keinginannnya. Tingginya motivasi ini juga ditunjukkan dari sikap positif terhadap perusahaan. Para karyawan merasa senang apabila pekerjaannya mencapai target yang ditetapkan perusahaa. Dari segi rangsangan pihak hotel dengan memberikan berupa bonus, tunjangan diluar gaji dirasa para karyawan masih kurang.

Hasil penelitian hipostesis ketiga penelitian yang sudah dilakukan diperoleh nilai $f$ hitung yaitu sebesar 237,591 dengan probabilitas $0,000<$ alpha $=0,05$. Karena signifikansi atau probabilitasnya jauh lebih kecil dari 0,05 dan perbandingan antara $F_{\text {hitung }}$ dan $F_{\text {tabel }}$ diperoleh hasil $F_{\text {hitung }}>F_{\text {tabel }}$ atau 237,591 $>4,14$ yang berarti $H_{a}$ diterima, maka model 
regresi dapat digunakan untuk memprediksi pengaruh variabel dependen atau produktivitas kerja karyawan. Jadi dari hasil pengujian secara simultan atau uji statistik $F$, dapat disimpulkan bahwa Kepuasan kerja dan motivasi kerja secara bersama-sama atau simultan berpengaruh signifikan terhadap produktivitas kerja karyawan pada Singaraja Hotel, dengan kata lain untuk meningkatkan produktivitas maka kepuasan kerja dan motivasi secara bersama-sama harus di tingkatkan pula dengan begitu maka produktivitas akan meningkat.

\section{SIMPULAN DAN SARAN Simpulan}

Kepuasan kerja berpengaruh terhadap produktivitas kerja karyawan pada Singaraja Hotel, Motivasi kerja berpengaruh terhadap produktivitas kerja karyawan pada Singaraja Hotel, Kepuasan kerja dan motivasi kerja berpengaruh secara simultan terhadap produktivitas kerja karyawan pada Singaraja Hotel.

\section{Saran}

Bagi pihak manajemen Singaraja Hotel agar lebih memperhatikan kepuasan kerja para karyawan sehingga motivasi kerja menjadi lebih baik, dengan demikian produktivitas kerja dapat meningkat, penelitian ini membuktikan bahwa kepuasan kerja dan motivasi dapat mempengaruhi produktivitas kerja karyawan. Pihak manajemen harus memperhatikan para karyawan melalui pemberian gaji yang sesuai dengan bidang pekerjaannya, serta memberikan bonus bagi karyawan memiliki keuletan dan ketekunan dalam memajukan hotel. Selain itu juga pihak hotel dapat memberikan jaminan kesejahteraan di masa depan, sedangkan bagi karyawan yang sudah bekerja cukup lama diberikan promosi berupa kenaikan jabatan.

Bagi peneliti selanjutnya yang tertarik untuk mengkaji aspek yang serupa yaitu pengaruh kepuasan kerja, motivasi terhadap produktivitas kerja karyawan diharapkan untuk mengembangkan penelitian ini dengan menggunakan populasi dan sampel yang lebih luas agar hasil penelitian lebih teruji keadalannya. Disamping itu, diharapkan untuk menguji variabel lain yang diduga kuat dapat mempengaruhi produktivitas kerja karyawan.

\section{DAFTAR PUSTAKA}

As'ad, M. 2009. Psikologi Islami: Seri Sumber Daya Manusia. Yogyakarta: Liberty.

Gaspersz, Vincent. 2009. Total Quality Management. Jakarta: PT Gramedia Pustaka Utama.

Ghozali, Imam. 2011. Aplikasi Analisis Multivariate dengan Program SPSS. Semarang: Badan Penerbit Universitas Diponegoro.

Hamid, Darmadi. 2010. Metode Penelitian Pendidikan. Bandung: Alfabeta.

Handoko, T. Hani. 2008. Manajemen Personalia dan Sumber Daya Manusia. Yogyakarta: Liberty.

Malonda. 2013. Kepuasan Dan Motivasi Kerja Pengaruhnya Terhadap Produktivitas Kerja Karyawan PT. Matahari Megamall. Skripsi. Jurusan Manajmen, Fakultas Ekonomi, Universitas Sam Ratulangi, Medan.

Manafe. 2018. Pengaruh Kepuasan Kerja dan Motivasi Kerja Terhadap Produktivitas Kerja Karyawan pada PT. Mitra Suara Sejati. Skripsi. Universitas Nusa Cendana, Kupang.

Marsono dan P.Sigit. 2001. Pupuk Akar. Jakarta: Redaksi Agromedia

Martoyo, S. 2011. Manajemen Sumber Daya Manusia. Yogjakarta: BPFE.

Melayu, Hasibuan S. P. 2012. Manajemen SDM. Edisi Revisi, Cetakan Ke Tiga Belas. Jakarta: Bumi Aksara.

Pramadewi. 2014. Pengaruh Kepuasan Kerja dan Motivasi Kerja Terhadap Produktivitas Kerja Karyawan Bagian Produksi PT.Sumber Sawit Sejahtera Pelalawan. Skripsi. Faculty of Economic Riau University.

Robbins, Stephen. 2011. Perilaku Organisasi. Jakarta: Penerbit Salemba Empat.

Sirait, T. Justine. 2006. Memahami Aspek-aspek Pengelolaan Sumber Daya Manusia dalam Organisasi. Jakarta: PT Grasindo.

Sugiyono. 2011. Metode Penelitian Pendidikan. Bandung: Alfabeta. 
Suwanto, dkk. 2011. Manajemen SDM dalam Organisasi Publik dan Bisnis. Bandung: Alfabeta.

Usman, Husaini. 2010. Manajemen Teori, Praktik Dan Riset Pendidikan Edisi 3, Cetakan 1. Jakarta: Bumi Aksara.

Wahyuddin, M. dan Prasetyo Edhi 2016. Program Pascasarjana Universitas Muhammadiyah Surakarta. Surakarta: Program Pascasarjana Universitas Muhammadiyah. 